\title{
THE CEREBROSPINAL FLUID IN POLIOMYELITIS
}

\author{
By J. N. Cumings, M.D., M.R.C.P. \\ Clinical Pathologist, National Hospital, Queen Square, London
}

Alterations in the composition of the cerebrospinal fluid (C.S.F.) are the rule at some stage in poliomyelitis; and numerous records are available which enable one to build up a complete picture of such changes at all periods of the disease. These changes differ at varying stages of the disease and some of the findings in the fluid will be described as they are found at three different periods. The other abnormal findings will be grouped together for later discussion.

\section{Pre-paralytic stage}

The most constant finding is an increase in the cell count, which may be as high as 2,000 per c.mm. Peabody (1917) obtained figures of from 36 to 1,980 per c.mm., Fraser (1913) of up to 880 per c.mm., and Lyon (1928) of up to 1,200 per c.mm. Counts below 30 per c.mm. are rare and cell counts below to per c.mm. are considered by Peabody as not occurring at this stage. The cells are most commonly lymphocytes and mononuclears, but polymorphonuclears have been found to be present in half the total number of cases in some epidemics, and may total as high as 50 per cent. of all cells present. In 193 I in an epidemic in New York City, as recorded by the International Committee for the Study of Infantile Paralysis (1932), only 40 out of 271 C.S.F.s gave a polymorph count of 25 per cent. or more. It would appear from the results found that it is essential to examine the C.S.F. immediately after withdrawal if any exact idea of the polymorph percentage is to be obtained, as some workers have found the number of polymorphs to fall rapidly on keeping the fluid.

The protein content of the C.S.F. is very slightly raised in some cases, although it may be within normal limits.

The levels of glucose and chloride in the fluid are both normal, and although there are a very few exceptional cases on record in which the glucose was higher or lower than normal it can be stated that at no time during the course of the disease is any abnormality in the amount of either of these two substances to be found.

\section{First week of paralysis}

A fairly high cell count is still present for the first few days of this week, but there is a diminution in their numbers during this period, and as they fall the number of polymorphs present also diminishes and finally disappears. Thelander, Shaw and Limper (193I) found counts of between 50 and 200 per c.mm., while Fraser found the polymorph percentage was on the average 34 per cent. of the total number on the second day, and only 6 per cent. on the third day after paralysis. Towards the end of the week the count often falls below 50 per c.mm.

Some workers in this field have found fewer cells in those cases in which the clinical signs are those due to bulbar involvement.

The protein content now tends to rise and is frequently up to $60 \mathrm{mgm}$. per cent. towards the end of this week, although both higher and lower figures have been recorded.

\section{Second and subsequent weeks}

The cell count now rapidly falls and often after the third week the count is less than ro per c.mm. The cells are mononuclear in type with the lymphocyte the predominant cell, but a few large mononuclears and even a plasma cell may on occasion be found. Polymorphs have now disappeared from the fluid. After the third week fluids with raised cell counts are quite uncommon.

The protein content of the C.S.F. during this period steadily increases for a few weeks and may reach $300 \mathrm{mgm}$. per cent., but usually after the fourth week a fall in the amount is to be noted. However, occasionally a high protein may be found after some weeks, and Greenfield and Carmichael (1925) have recorded figures of up to $300 \mathrm{mgm}$. per cent. eight weeks after the onset of paralysis. Finally the protein content returns to normal.

\section{Other abnormal findings}

Fibrin clot. A fine fibrin coagulum may form at any stage of the disease and although it is relatively uncommon in the acute stages, it is at this stage that it will cause the greatest difficulty, as it is also seen in tuberculous meningitis. A fibrin clot is most likely to be found in fluids with a raised protein content, and it can be found in a fair proportion of such fluids provided that the C.S.F. is neither shaken nor kept in the cold. Greenfield and Carmichael found that such clots formed in all fluids containing more than $90 \mathrm{mgm}$. per cent. of protein.

Lange. It has been known that there are changes in the lower dilutions so that curves such 
as 0122110000 are fairly common, but in England relatively little attention has been given to the result of the Lange curve as a diagnostic feature, although Drury and Sladden (1939) found this test to be of value. In America, however, more stress has been laid on this method. Some workers there (Jeans and Johnston, I9I7) held that an abnormal Lange curve, especially in the absence of other chemical abnormality, was in favour of poliomyelitis as opposed to tuberculous meningitis or meningism.

Globulin. Almost all workers report an increase of globulin in the C.S.F. and it frequently remains positive ur.til the fourth week.

Other examinations such as estimations of haemolysins and of . omplement have been made but are of no frictical value.

\section{Differential diagnosis}

Tuberculous meningitis. This condition will show a fall of chlorides and of sugar in the presence of increased cells and protein and a fibrin clot; thus the completely normal chloride and sugar levels found throughout the course of poliomyelitis are of supreme importance. Tubercle bacilli may also be found in the clot in most cases of tuberculous meningitis.

Encephalitis lethargica. The type of cell count is of value here. Polymorphs in the C.S.F. are not found in encephalitis lethargica but are found early in poliomyelitis, and it is only in the early stages that clinical difficulty arises. Further, a fibrin clot is not found in encephalitis lethargica.

Acute polyneuritis. The protein is usually raised to a higher level in proportion to the number of cells present in polyneuritis and so will help to distinguish the two conditions in the early stages. It is only at such a time that any difficulty in diagnosis will arise.

It will probably be of help to illustrate the description given above by recording some actual C.S.F. findings in cases of poliomyelitis that have been seen at different stages of the disease. Typical examples are given and two cases chosen for each period of the disease in order to illustrate the degree of variation in the findings that may be seen. The diagnosis of poliomyelitis was not made in either Case 1 or Case 2 until after the result of the C.S.F. findings was known, but in the other four cases the correct clinical diagnosis was made before lumbar puncture.

CASE I. $A$ woman of 27 years seen 24 hours before paralysis, and six days after the commencement of the illness. The fluid was clear and colourless zvithout a clot.

Cells, $3^{8}$ per c.mm. Polymorphs
Protein, 0.110 gm. per cent.

Globulin Positive

(Nonne-Apelt)

Lange, 0000000000

Chlorides, 0.720 gm. per cent.

Sugar, within normal limits.

CASE 2. A boy of 12 seen before the onset of $\frac{\bar{D}}{\vec{D}}$ paralysis and after three days illness. The fluid roas slightly turbid.

Cells, 860 per c.mm.

Protein, 0.045 gm. per cent.

Globulin, not increased.

Lange, no change.

Chlorides, $0.73 \mathrm{gm}$. per cent.

Sugar, within normal limits.

CASE 3. A girl of ' I y years seen during the first week of paralysis (legs and arms). The fluid was $\vec{\omega}$ clear and colourless without a clot.

Cells, 18 per c.mm.

Protein, 0.08 gm. per cent.

Globulin; weakly positive.

Lange, 0001000000 .

CASE 4. A man of 38 seen during the first week

of paralysis. The fluid was colourless with a fin coagulum.

Cells, 3 I lymphocytes per c.mm.

Protein, 0.220 gm. per cent.

Globulin, positive.

Lange, 0001 1122 I0.

Chlorides, 0.74 gm. per cent.

CASE 5. $A$ boy of 4 seen at the end of the second week of paralysis. The fluid was clear with a coagulum.

Cells, 2 lymphocytes per c.mm.

Protein; 0.30 gm. per cent.

Globulin, positive.

Lange, 0000000000 .

CASE 6. A girl of 13 seen during the third week of paralysis. The fluid was clear and colourless.

Cells, 8 lymphocytes per c.mm.

Protein, $0.120 \mathrm{gm}$. per cent.

Globulin, positive.

Lange, 0001000000.

\section{BIBLIOGRAPHY}

DRURY, J. C., and SLADDEN, A. F. (1939), B.M.Y., 2, 557. FRASER, F. R. (1913) $\mathscr{Y}$. Exper

GREENFIELD, G. and CARMICHAEL, E. A (1025), "The Cerebro-Spinal Fluid in Clinical Diagnosis.' London. Macmillan 0 and Co.

INTERNATIONAL COMMITTEE FOR THE STUDY OF INFANTILE PA.RALYSIS (1932), 'Poliomyelitis.' Baltimore, The Williams and Wilkins Co

JEANS, P. C., and JOHNSTON, M.R. (1917), Am. Y. Dis. Child., I33 239.

LYON, G. M. (1928), Ibid., 36, 40.

PEABODY, F. W (1917), Boston $M$. \& S.7., 176, 637

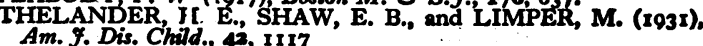

